\title{
From Law and Order to Pacification: Britain's Suppression of THE ARAB Revolt in Palestine, 1936-39
}

\author{
MatThew Hughes
}

This article examines British buman rights abuses against noncombatants during the 1936-39 Arab Revolt in Palestine, contextualizing brutality in Palestine within British military practice and law for dealing with colonial rebellions in force at the time. It shows that the norms for such operations, and the laws that codified military actions, allowed for some level of systemic, systematic brutality in the form of "collective punishments" and "reprisals" by the British army. The article also details the effects of military actions on Palestinian civilians and rebels and describes torture carried out by the British on Palestinians. Finally, it highlights a methodological problem in examining these sorts of abuses: the paucity of official records and the mismatch between official and unofficial accounts of abuse during counterinsurgency.

IN APRIL 1936, the Palestinians launched a countrywide revolt against British rule in Mandatory Palestine and the official policy of support for Jewish immigration to the country. While interrupted by a cease-fire from October 1936 to September 1937, the rebellion reached its peak of intensity in 1938 , before petering out in mid- to late 1939 with the approaching war in Europe. For long stretches of the rebellion, the British lost control of Palestine, including many major towns and, for about five days in October 1938, the Old City of Jerusalem. This was a substantial colonial revolt requiring a remarkably large force deployment by Britain: two full infantry divisions, or some twenty-five thousand men, with supporting arms by 1938 . Most British infantry regiments served in Palestine at one time or another between 1936 and 1939.

The severity of the rebellion, along with a shortage of troops in Palestine when it erupted, limited Britain's initial response. By the time regiments were en route to Palestine and the army was ready for protracted military action in autumn 1936, a royal commission of inquiry led by Lord Peel was on its way to the country to investigate the causes of the revolt and determine the

\footnotetext{
Matthew Hughes is a reader in history at Brunel University. He currently holds the U.S. Marine Corps University's Major-General Matthew C. Horner Distinguished Chair of Military Theory, funded by the Marine Corps University Foundation through the gift of Mr. and Mrs. Thomas A. Saunders. Dr. Hughes also acknowledges the support of the British Academy, the Trustees of the Liddell Hart Centre for Military Archives, Bahjat Abu Gharbiyah, and Itamar Radai.
}

Journal of Palestine Studies Vol. XXXIX, No. 2 (Winter 2010), pp. 1-17, ISSN: 0377-919X; electronic ISSN: $1533-8614$. (c) 2010 by the Institute for Palestine Studies. All rights reserved. Please direct all requests for permission to photocopy or reproduce article content through the University of California Press's

Rights and Permissions website, at http://www.ucpressjournals.com/reprintInfo.asp. DOI: jps.2010.XXXIX.2.1. 
territory's future, resulting in a temporary suspension of guerrilla activity.The commission's failure, and notably the publication in summer 1937 of its report recommending the partition of Palestine into Arab and Jewish states, triggered a sharp recrudescence of the rebellion by early autumn. Though the British army had ramped up its repression as of October 1937, at the same time increasingly taking charge from the police and civil authorities, the need to hold back troops for a possible European war restricted what it could do. The Munich settlement in September 1938 freed it from this constraint, enabling it to send strong reinforcements to Palestine. Beginning in October 1938, British troops started to flood the country, making possible the tough, extensive repression in the field that eventually defeated the rebellion. The influx of troops and the gradual introduction of military courts and forms of martial law as of autumn 1937 boosted the army's position, and ordinary Palestinians would feel the brunt of Britain's military power.

\section{LAW AND ORDER}

Britain had long experience with colonial rebellions and had practical traditions and legal systems in place to deal with them. As far back as 1896, an influential volume by Colonel C. E. Callwell titled Small Wars:Their Principles and Practice described counterinsurgency methods from places such as the northwest frontier of India that would later be employed in Palestine:

The adoption of guerrilla methods by the enemy almost necessarily forces the regular troops to resort to punitive measures directed against the possessions of their antagonists. It must be remembered that one way to get the enemy to fight is to make raids on his property-only the most cowardly of savages and irregulars will allow their cattle to be carried off or their houses to be destroyed without making some show of resistance.... [I]t has generally been found very useful to send raiding parties consisting of mounted men great distances to carry off the enemy flocks and herds or to destroy encampments and villages. ${ }^{1}$

While concentrating on the military tactics to be used against local rebels, Callwell also provided details on how to deal with the civilian population who, as "uncivilised races attribute leniency to timidity," must be "thoroughly brought to book and cowed or they will rise again." ${ }^{2}$ Collective punitive measures such as "destroying villages, carrying off livestock and trampling down crops and so on," already well established in irregular "small" wars against guerrillas by the time Callwell wrote his book, were used in the Boer War (1899-1902), during the Egyptian and Iraqi revolts (1919-20), in India, and during the Irish War of Independence (1919-21). ${ }^{3}$ In the 1930s, Major General Sir Charles Gwynn and Colonel H. J. Simson-the latter served in Palestine during the revoltdeveloped Callwell's lessons, applying them to imperial hot spots such as Palestine and arguing that such situations required firm military rule. ${ }^{4}$ 
The British military legal system supported harsh measures by troops fighting insurgents, especially those operating outside the United Kingdom. Soldiers in Palestine were bound by the King's Regulations (reissued in 1935 with a section titled "Duties in Aid of the Civil Power" that largely related to troops' conduct in the United Kingdom) and the 1929 Manual of Military Law, a bulky hardback volume whose key points were abridged in pocket-sized pamphlets such as Notes on Imperial Policing, 1934 and the 1937 Duties in the Aid of the Civil Power that officers could take with them on operations. ${ }^{5}$ The 1929 manual, an updated compilation of periodically reissued manuals of law stretching back to 1884 , forbade stealing from and maltreating civilians. It also made clear that soldiers were subject to civil as well as military law and that an "act which constitutes an offence if committed by a civilian is none the less an offence if committed by a soldier." 6

That said, the manual also established a legal framework for shooting rioters and allowed for "collective punishments" and "retribution," whose loose definitions gave field commanders considerable leeway in interpreting the rules. The 1929 law clearly stated that where coercion was required or where terrorism needed to be checked, collective punishment and reprisals that would "inflict suffering upon innocent individuals," were "indispensable as a last resource." According to the law, "The existence of an armed insurrection would justify the use of any degree of force necessary effectually to meet and cope with the insurrection." 8

Strictly speaking, the 1929 manual applied these punitive laws only to civilians living under military occupation during wartime. In the case of Palestine, the military rule imposed by Britain in 1917 was lifted in 1920 with the establishment in the country of a civil government, but collective punishment was explicitly permitted under the Ordinances and Orders in Council introduced in Palestine by the Mandate authorities in 1922 and regularly updated thereafter. Indeed, a "Collective Responsibility for Crime Ordinance" dates back to $1921 .{ }^{9}$ The British used these local laws when implementing collective punishments on Palestinians and villages, referring to them after April 1936 as "emergency" laws. The 1934 and 1937 pamphlets cited above provide further proof that the principles (and practice) of collective punishment and reprisals were an established part of rule and repression in Palestine.

Civil proceedings against servicemen for individual offenses during counterinsurgency operations were theoretically possible, but a strict reading of the military law in force meant that in practice soldiers had little reason to fear disciplinary action for most excesses, including theft, torture, and assault. Victims could take out civil proceedings only against individual soldiers (the state being immune from prosecution until the 1947 Crown Proceedings Act), and even then, it had to be proven that the soldiers were acting beyond their lawful operational orders. This was not practicable. One Palestinian claimed that soldier "number 65 " had beaten him, not realizing that all the men from that unit, the York and Lancaster Regiment (formerly the 65th Foot), carried this number 
on the left side of their helmets. ${ }^{10}$ This author has found only one successful prosecution of servicemen in Palestine-that of four British police officers who blatantly executed an Arab prisoner in a street in Jaffa.The case was prosecuted only because a number of non-British European residents witnessed the incident and complained. (The complaints of Arabs never resulted in a prosecution.) The killing led to an investigation and the charging of the four officers who received minimal sentences, reduced on appeal. ${ }^{11}$

After September 1936, the army established military courts and regulations in Palestine that were separate from the ordinary civil courts and not open to the usual legal challenges.The shift from a civil to a military judiciary was partial and gradual, but the general effect was that legal appeals by Arabs would either fail or not be allowed. ${ }^{12}$ While British forces in Palestine during the revolt officially operated as an aid to the civil power, conditions in the country in practice approached martial law, a situation that further eased civil limits on soldiers' behavior.The British never instituted full (or "real") martial law in Palestine, but in a series of Orders in Council and emergency regulations after 1936 they issued "statutory" martial law, a level between semimilitary rule under civil powers and full martial law under military powers where the army and not the civil high commissioner had the upper hand. ${ }^{13}$ After September 1937, when the rebellion intensified, the army increasingly took charge in Palestine, with the "full power of search and arrest, independent of the police, and the right to shoot and kill any man attempting to escape search or ignoring challenges." ${ }^{14}$

Thus, starting from late 1937 or early 1938, Palestine was under de facto if not de jure martial law of some sort. Nor was military rule much affected by the international laws in place at the time (e.g., the succession of Geneva conventions from 1864 to 1929 and the Hague conventions of 1899 and 1907) as these dealt mainly with the conduct of war and the treatment of prisoners of war (POWs) rather than with the maltreatment of civilians. Britain had classified the Arab Revolt as an internal insurrection and not an international war, thereby denying POW status to captured Arab fighters and allowing them to be treated as civilian criminals subject to ordinary civil law modified by conditions of martial law, such as the death penalty for carrying a weapon or ammunition.To be fair, the British never entirely removed civil authority in Palestine from the decision-making process, but by 1938, the high commissioner tempered rather than directed the actions of British armed forces. When Sir Arthur Wauchope, the high commissioner in place for the first phase of the revolt, looked for a political solution to the revolt and challenged army efforts to institute martial law, he antagonized the armed forces who thought him too lenient and referred to him as a "washout" and "ga-ga."15 In March 1938, the Colonial Office replaced him with the more compliant Sir Harold MacMichael.

\section{Pacification}

Britain's most spectacular single act of destruction in Palestine was the demolition of large parts of the old city of Jaffa just two months after the 
outbreak of the rebellion. Beginning on 16 June 1936 and continuing in several phases to the end of the month, the British army, ostensibly to improve the sanitation system, cut wide pathways through the old city with large gelignite charges to allow military access to, and control of, a rebel-held area that had previously eluded military control. ${ }^{16}$ In the process, the army blew up between 220 and 240 multioccupancy buildings, rendering homeless up to 6,000 Palestinians, most of whom were left destitute, having been told by airdropped leaflets on the morning of 16 June to vacate their homes by 21:00 hours of the same day. ${ }^{17}$ Some families were left with nothing, not even a change of clothes. ${ }^{18}$ As a British army intelligence officer observed, "That will fucking well teach them." ${ }^{19}$ Such vandalism shocked the British chief justice in Palestine, Sir Michael McDonnell, who frankly condemned the action, for which he was dismissed. ${ }^{20}$ Under strict censorship and therefore unable to express outrage at the destruction of the heart of old Jaffa, the Palestinian press resorted to irony. Jaffa's leading newspaper, Filastin (Palestine), reported how the "operation of making the city [Jaffa] more beautiful is carried out through boxes of dynamite." ${ }^{21}$ Al-Difa" (the Defense) headlined the assault with "Goodbye, goodbye, old Jaffa, the army has exploded you."22 Many Jaffans, now refugees, ended up living in shanty towns, an ironic finale to an action officially depicted as an attempt to "improve" health and sanitation.

While the destruction of old Jaffa did not contravene the legal framework and principles governing collective punishment discussed in the previous section, the "pacification" permitted under these rules easily elided brutality and torture and blurred the distinction between official and unofficial punishment. Nor was there a clear division between what constituted "punishment," "reprisal," or simply a "search," a looseness facilitated by the leeway given to officers in the field and by the fact that British regiments responded differently to the stresses of suppressing the revolt. Most often, the widespread use of punitive actions and destructive and brutal reprisals stopped short of actual atrocity, but such actions were central to British military repression after 1936 and constituted the core experience for Palestinians during the revolt.

The level of damage varied considerably depending on time, place, and the regiment involved, but whatever the law sanctioned, destruction and vandalism were certainly a systematic, systemic part of British counterinsurgency operations. The destruction could take the form of blowing up houses-often the most impressive ones in the village-or vandalizing and smashing household effects. Alongside the destruction, servicemen often looted properties, though this was not officially sanctioned. There were also "reprisals" in the form of heavy collective fines, forced labor, and punitive village occupations by government forces for which villagers bore the cost. One Arab rebel noted that the British army was unable to "strike" the fighters so it had to resort to "revenge" and "collective punishment." ${ }^{23}$ Using air support, radio communications, intelligence, collaborators, and mobile columns, the British improved their tactics against the rebel bands, but they never were able to defeat an elusive enemy in open battle in rough terrain, so they adopted a two-pronged 
military approach, targeting enemy fighters and the civilians on whom they relied for support.

The June 1936 operation in Jaffa was atypical as troops by and large avoided large-scale destruction in the bigger towns, although parts of Jenin were destroyed following the assassination of a British colonial official,W.S.S. Moffat, in the town in August 1938. Generally, it was the smaller, remote villages in rural areas of Palestine that were singled out for incremental devastation. Villages that proved particularly recalcitrant would be entirely demolished, reduced to "mangled masonry," as happened to the village of Mi'ar, north of Acre in October 1938. ${ }^{24}$ On other occasions, the British used sea mines from the battleship HMS Malaya to destroy houses. ${ }^{25}$ Sometimes the charges laid were so large that neighboring houses collapsed or flying debris hit bystanders. The laying of oversized explosive charges by Royal Engineers to effect maximum damage was intentional. British troops even made Palestinians demolish their own houses, brick by brick. ${ }^{26}$

During army searches, soldiers would surround a village and then detach and guard the women and children separately from the men, who were often held in wire "cages" during protracted searches. In the meantime, soldiers would "search" the empty houses, often destroying everything therein, burning grain and pouring olive oil over household food and effects. ${ }^{27}$ The village men were also "screened" by having them pass in front of hooded or hidden Arab informers who would nod when a "suspect" was found, or by British officials checking their papers against lists of suspects. If the army was following up an intelligence lead and looking for a suspect or hidden weapons, any destruction was incidental to the searching of properties. Troops also used primitive metal detectors on such operations. ${ }^{28}$ The army used the excuse of weapons searches to justify damage if there were complaints.

Destruction of property was not part of soldiers' training, but once prompted they did the job with gusto.The officer tasked with checking on a search carried out in one village reprimanded a corporal who left intact a beautiful cabinet full of glassware, and then proceeded to destroy the cabinet and its contents himself. ${ }^{29}$ The British designated some searches as "punitive." Recalling such raids, a private remarked,"Oh yes, punitive.You smashed wardrobes with plates, glass mirrors in[,] and furniture, anything you could see you smashed." ${ }^{30}$ The local district officer instructed Colonel J. S. S. Gratton, then a subaltern with the Hampshire Regiment, that the unit's search of Safad was a punitive raid, meaning that (in Gratton's words) they could "knock the place about":

And it's very alien to a chap like you or me to go in and break the chair and kick chatty in with all the oil in and mixed it in with the bedclothes and break all the windows and everything. You don't feel like doing it. And I remember the adjutant coming in and saying, "You are not doing your stuff. They're perfectly intact all those houses you've just searched. This is what you've got to do." And he picked up a pick helve 
and sort of burst everything. I said, "Right OK," so I got hold of the soldiers and said, "this is what you've got to do," you know. And I don't think they liked it much but once they'd started on it you couldn't stop them. And you'd never seen such devastation. ${ }^{31}$

Following the search and cordon of the town of Safad by the Hampshire Regiment, a senior police officer in Palestine, Sir Charles Tegart, noted simply that the soldiers "did their work thoroughly," adding that local villagers had little sympathy for the townsfolk of Safad, who had hitherto been spared and who would now "know what has been happening to us." ${ }^{32}$ For the soldiers, their job in Palestine was simply "to bash anybody on the head who broke the law, and if he didn't want to be bashed on the head then he had to be shot. It may sound brutal but in fact it was a reasonably nice, simple objective and the soldiers understood it." ${ }^{33}$ Hilda Wilson, a British school teacher in Palestine, concluded that the reason for the soldiers' destructiveness was that they were "bored stiff" and had no social amenities, compounded by the alienation that they felt serving "in a distant country among people who, they are told, are the 'enemy'."34

Variations between the "official" history of counter-rebel operations and village searches and less formal versions of events suggest a hidden historywhen evidence can be found.The British response to the assassination of two Black Watch Regiment soldiers near Jerusalem's Jaffa Gate on 5 November 1937 is a case in point. In what would be classed as an "official" account, General Sir Archibald Wavell, the overall commander in Palestine, remarked on the restraint shown by the Black Watch (coincidentally, his old regiment) on a subsequent operation against Silwan, the village south of the city blamed for the attack, although he did note that a suspect died "falling over a cliff." ${ }^{55}$ In Ha'Aretz (the Land) it was reported how after tracker dogs led the authorities to the village, a villager was hospitalized after falling off a cliff, while soldiers shot dead one man and wounded another. The authorities then sealed the village, forbidding villagers to leave without a permit and requiring all males to report every evening to the police. The village was also forced to pay for a twenty-man police post. ${ }^{36}$ More graphic accounts of what happened in Silwan are to be found in the private papers of soldiers present at the scene.A North Staffordshire Regiment officer recorded in his diary that Black Watch men beat twelve Arabs to death in Silwan with rifle butts. ${ }^{37}$ The assailants had apparently left the two dead soldiers face down with their kilts raised and buttocks exposed, further enraging their comrades: "An insult the local Arabs suffered for." ${ }^{38}$ Another British officer recalled that the "Jocks" (slang for the Scottish) were uncontrollable after their comrades' deaths and so the high command gave them eight hours to "search" Silwan without rifles: "a lot of Arabs were very sorry that it had happened." 39

Arab sources also provide information about the conduct of soldiers. For example, in June 1936, Muslim religious leaders wrote to the high commissioner 
detailing how police officers on operations "stamped" on things, "smashed doors, mirrors, tables, chairs, wardrobes, glass, porcelain," and ripped women's clothing and bed linen. Soldiers mixed in margarine and oil with foodstuffs, trampled on "holy books," and destroyed wooden kitchen utensils as well as glasses, clocks, smoking pipes, and basins. ${ }^{40}$ That same month, the Arab Higher Committee, the Palestinians' supreme leadership, protested to the high commissioner about police and soldiers hitting innocent people; insulting their dignity; stealing items; and destroying furniture, goods, and provisions. ${ }^{41}$ Bahjat Abu Gharbiyah, a Palestinian rebel, gunman, and journalist during the revolt, wrote in his memoirs how servicemen "searched houses, each one by itself, in a way that was sabotaging on purpose":

[T] hey looted some of the assets of the houses, and burnt some other houses, and destroyed provisions/goods.After putting flour, wheat, rice, sugar and others together, they added all the olive oil or petrol they could find. And in every search operation they destroyed a number of houses of the village and damaged others. They also put signs on other houses to destroy them in the future if there are any incidents near the village, even if that incident is only cutting telephone wires. ${ }^{42}$

Arab villagers were trapped between the hammer of rebel operations and the anvil of British forces. ${ }^{43}$ In one typical example, when the police went to investigate a report that rebels had blocked the road near the village of Shafa 'Amr with trenches and roadblocks, the "local inhabitants protested that they had been compelled to do this sabotage by rebel gangs, but this excuse did not spare them from a fine of $£[P] 700$ [Palestine pounds]," and they had to repair the road. ${ }^{44}$ The collective fines imposed were a heavy burden for Palestinian villagers, especially when the authorities also took away all their livestock, smashed up properties, imposed long curfews, set up police posts, blew up houses, and detained some or all of the menfolk in distant detention camps. Fines varied but could be as high as £P5,000 and they had to be paid promptly in cash or in the form of produce such as animals, eggs, and cereals. ${ }^{45}$ To make matters worse, the rebels also fined or robbed villages for not supporting the revolt, £P1,000 in one case, £P10-100 per household in another. ${ }^{46}$ To give a sense of the magnitude of the fines, in the late 1930s a British police officer of constable rank earned a basic pay of £P11 per month rising to £P18 for an assistant inspector "all found," a wage that drew police recruits to Palestine. By contrast, Rosemary Sayigh has estimated the average yearly wage of a Palestinian rural family at between $\$ 25-30 .{ }^{47}$ In the village of al-Tira (or Taybeh; the transliteration from Arabic to Hebrew to English is not clear), peasants responded to a fine of £P2,000 by picking up what they could carry and leaving. ${ }^{48}$

If villagers were unable to pay collective fines in currency, they paid in produce:"As usual police were called to do the dirty work, collecting chickens, 
eggs and grain from each family and taking them to Haifa for sale." ${ }^{49}$ Police activity often went beyond the forced requisitioning of produce, as when the police went to a village after rebels had killed some "wogs" and promptly indulged in indiscriminate violence against the villagers rather than the rebels. "By the time we arrived of course they had vanished into the blue but we had orders to decimate the whole place which we did, all animals and grain and food were destroyed and the sheikh and all his hangers on beaten up with rifle butts. There will be quite a number of funerals their [sic] I should imagine." ${ }^{50}$ Villagers were in permanent debt as their mukhtars (headmen) attempted to gather official fines from their penniless and hungry villagers. Certain villagers were also required to produce bonds of up to $\$$ P100 and additional sureties to ensure their good behavior. Failure to pay could result in imprisonment. ${ }^{51}$

The British ratcheted up their punitive actions, especially after September 1937. When on 18 February 1938 rebels ambushed a car twelve miles south of Haifa, killing an RAF officer and badly wounding a British woman passenger near the "bad" village of Ijzim ("good" and "bad" villages are recurring terms in British files), the authorities brought in a tracker dog to pick up the scent:

The trail was expected to lead up the Wadi Mughar to the bad village of Igzim [Ijzim in literary Arabic], and B Company, less one platoon, under Major Clay was detailed as dog escort. The fourth platoon was given the task of rounding up 2,300 goats and 200 sheep for confiscation as a punishment on the inhabitants of the area in which the crime was committed. The dog quickly took up the trail and moved up the Wadi Mughar to Igzim, where it "marked" a house on the northern end of the village. It was then taken back to the coast road and put onto another clue, again tracking back to the same village, but to a house opposite the first one. When searched, however, the owners of both houses were absent. The whole village was then cordoned and searched, while reports were sent to Brigade Headquarters in Haifa on the result of the dog's tracking. Later in the morning orders were received to demolish the two houses marked by the dogs. ${ }^{52}$

A policeman present at Ijzim, Sydney Burr, wrote to his parents about the brutality of the "search," which was so harsh as to prompt a complaint about army behavior from the Anglican Mission in Palestine. ${ }^{53}$

The use of Doberman tracker dogs, specially imported from South Africa, gave a spurious exactitude to an operational method that relied on villagers doing the work of the British army, suppressing the rebels on pain of the collective punishment and reprisals that would inevitably ensue if there were any rebel actions in the area. Critics alleged that tracker dogs always picked out some suspect on parade; on one occasion after a robbery, the dog followed a scent to a distant village, leading the police to an old blind man and then barked at him, "proving" that he was the robber. ${ }^{54}$ Once the tracker dog had 
marked a Palestinian or a dwelling, the police invariably "found" some bullets to confirm guilt and the courts then took over, with hanging the ultimate penalty for the possession of even one round.

\section{Unofficial ACts of Violence}

Excepting the endemic problem of soldiers stealing and taking "souvenirs" during searches-which even periodic personal searches of men by noncommissioned officers under officers' orders failed to stop-the actions described in the previous section were within the law and (generally) acceptable under British military rule. ${ }^{55}$ They formed part of the official policies designed to break the resolve of the Palestinian peasantry. But there were also unofficial acts of brutality committed by rank-and-file servicemen that were not permitted, stretching beyond "official" collective punishment and fines to include much more violent acts directed not only at property but also at individuals. While these ad hoc outrages were often soldiers' revenge against rebel attacks, they also had the unintended effect of helping the suppression of the revolt by further terrorizing ordinary Palestinian civilians (and rebel fighters). Officers operating in the field seem to have accepted or even sanctioned a level of casual brutality by their men. Some level of personal pleasure in causing suffering also played its part. As the commanding officer of the Essex Regiment-a unit that acted very brutally in Ireland in the early 1920s-noted at the end of 1937, punitive search operations against Arab villages were "enjoyed by all ranks." 56

A common unofficial British army practice was to make local Arabs ride with military convoys to prevent mine attacks. Soldiers carried them or tied them to the bonnets of lorries or put the hostages on small flatbeds at the front of trains, all to prevent mining or sniper attacks."The naughty boys who we had in the cages in these camps" were put in vehicles in front of the convoy for the "deterrent effect," as one British officer put it. ${ }^{57}$ The army told the Arabs that they would shoot anyone who tried to run away. ${ }^{58}$ Soldiers would brake hard at the end of a journey and then casually drive over the Arab who had tumbled from the bonnet, killing or maiming him. As Arthur Lane, a Manchester Regiment private, later candidly recalled in an oral interview:

[W] hen you'd finished your duty you would come away nothing had happened no bombs or anything and the driver would switch his wheel back and to make the truck waver and the poor wog on the front would roll off into the deck. Well if he was lucky he'd get away with a broken leg but if he was unlucky the truck behind coming up behind would hit him. But nobody bothered to pick up the bits they were left.You know we were there we were the masters we were the bosses and whatever we did was right. ... Well you know you don't want him anymore. He's fulfilled his job.And that's when Bill Usher [the commanding officer] said that it had to stop because before long they'd be running out of bloody rebels to sit on the bonnet. ${ }^{59}$ 
British troops also left Arabs wounded on the battlefield to die ${ }^{60}$ and maltreated Arab fighters taken in battle, so much so that the rebels tried to remove their wounded or dead from the field of battle. ${ }^{61}$ Lane, the soldier with the Manchester Regiment, was in a clash with guerrillas in which several British soldiers had been killed and he provides a graphic, disturbing account of what happened to the Arabs captured after a firefight who were taken back to the military camp and tied to a post:

[T] hey were in a state and they were really knocked about.... whoever had done it when they got them on the wagons to bring them back to camp the lads had beat them up, set about them ... [the interviewer asks him with what] ... Anything. Anything they could find. Rifle butts, bayonets, scabbard bayonets, fists, boots, whatever.There was one poor sod there he was I would imagine my age actually and I'd heard people say in the past that you could take your eye out and have it cleaned and put it back and I always believed it but it's not so because this lad's eye was hanging down on his lip, on his cheek. The whole eye had been knocked out and it was hanging down and there was blood dripping on his face.

When asked why the soldiers had done this, Lane replied simply, "Same as any soldier. I don't care whether he's English, German, Japanese or what. He's the victor he's the boss and you accept the treatment that he gives you. I don't care what you say.... There's a beast in every man I don't care who he is. You can say the biggest queen or queer that you come across but there's a beast in him somewhere and in a situation like that it comes out." 62

These excesses were soldiers' responses to rebels wounding or killing comrades in battles, with prisoners or local villagers being convenient targets for revenge attacks. ${ }^{63}$ British soldiers also bayoneted innocent Arabs ${ }^{64}$ and gunned down Arab fighters en masse as they came out to surrender near Jenin:

At one time the Ulsters and West Kents caught about 60 of them [Arab guerrillas] in a valley and as they walked out with their arms up mowed them down with machine guns. I inspected them afterwards and most of them were boys between 16 and 20 from Syria.... No news of course is given to the newspapers, so what you read in the papers is just enough to allay public uneasiness in England. ${ }^{65}$

There is also the question of the methods used by Orde Wingate's "Special Night Squads" that mixed British servicemen with Jewish fighters and pitted them against the Arabs in Galilee- "extreme and cruel" noted one colonial official, Hugh Foot, a force that tortured, whipped, executed, and abused Arabs according to Jewish sources. ${ }^{66}$

The brutality of the Palestine police and prison service had some official sanction. Frances Newton, a British resident of Haifa sympathetic to the Arabs 
(and eventually banned from the country), noted that after the murder of the assistant district commissioner Lewis Andrews in September 1937 by Arab gunmen, the police asked permission to use torture to extract information from suspects, which the Colonial Office granted."Several of the leading police officers in Jerusalem refused to countenance it. One of them has since left the country." ${ }^{67}$

Tegart, the senior officer mentioned above, who had been brought in to Palestine from the India police, established torture centers, known euphemistically as "Arab Investigation Centers," where suspects got the "third degree" until they "spilled the beans." A major such center in a Jewish quarter of West Jerusalem was closed only after colonial officials including District Commissioner Edward Keith-Roach complained to the high commissioner. ${ }^{68}$ The British army divisional commander in Palestine, Sir Richard O'Connor, also wrote of the use of the "third degree" and "black and tan methods" (oft-used phrases), the latter a reference to the British paramilitary unit known as the "Black and Tans" that operated against Irish rebels in Ireland's war of independence. ${ }^{69}$ In an interview with this author,Abu Gharbiyah stated that torture ended only after the issue was discussed in Britain's Parliament. ${ }^{70}$ Interrogators used the "waterboarding" torture at these centers. ${ }^{71}$ Keith-Roach raised the issue that the "questionable practises" carried out by Criminal Investigation Department officers on suspects were counterproductive, both in terms of the information gathered and the effect that they had on local people's confidence in the police. ${ }^{72}$

Accounts in both Arabic and English also detail torture-of Arabs being blown to bits in vehicles after being forced along roads in which the British had placed mines; of British operatives placing "terrorist" bombs in Haifa; of detainees being left in open cages in the sun without sustenance; of men being beaten with wet ropes, "boxed," and having their teeth smashed; and of men having their feet burnt with oil. ${ }^{73}$ Those who were "boxed" were beaten until knocked unconscious, "needles" were

Guards used bayonets on sleep-deprived Arab detainees and made them wear bells around their necks and then dance. used on suspects, dogs were set upon Arab detainees, and British and Jewish auxiliary forces maltreated Arabs by having them hold heavy stones and then beating them when they dropped them. Guards also used bayonets on sleep-deprived men and made them wear bells around their necks and then dance. ${ }^{74}$ Arab

detainees in Palestine's prisons protested the extreme treatment meted out by guards in petitions made through the Anglican Mission. Prisoners jumped to their deaths from high windows to escape their captors, had their testicles tied with cord, were tortured with strips of wood studded with nails, had wire tightened around their big toes, and hair was torn from their faces and heads. Special instruments were used to pull out fingernails, red-hot skewers were used on detainees, prisoners were sodomized, and boiling oil was used on them, as were intoxicants (morphine, cocaine, and heroin). There were also electric shocks, water funneled into suspects' stomachs, and mock executions. $^{75}$ 
At least two outrages by British forces in Palestine meet the dictionary definition of an atrocity and suggest an "official" military operational method of destruction that could get out of hand and descend into "unofficial" violence. These two incidents, for which there is enough evidence to permit a reasonably full reconstruction, occurred at al-Bassa, a village in Acre district near the Lebanese border, in September 1938, and at Halhul, a village near Hebron, in May $1939 .{ }^{76}$ In the case of al-Bassa, soldiers retaliated against the village after four of their comrades were killed in its vicinity by a rebel land mine. The logic was that when Arab insurgents laid a mine they informed nearby villages of its placement, making the local villagers responsible. In fact, a policy of retaliation in such cases fitted in with the collective responsibility detailed above and at the same time discouraged further rebel attacks. Within twentyfour hours, al-Bassa was burned to the ground and at least twenty villagers were herded onto a bus that was forced to drive over a land mine buried by the soldiers, after which other villagers were forced to dig a pit and bury the bodies. ${ }^{77}$ As for Halhul—one of the villages designated as "bad" by the British for its rebel sympathies-the brutal treatment meted out was the result of the army's attempt to extract intelligence from the villagers on the whereabouts of weapons caches. While brutality was not uncommon in attempts to obtain information, in this case some fifteen elderly male villagers-all of whom had been herded into cages and left out in the open in intense heat for days with inadequate water-died of thirst and exposure. Halhul and al-Bassa were not isolated incidents. The Anglican Mission in Jerusalem listed twenty-two villages and towns in which troops inflicted single or multiple outrages, sometimes over a period of months. ${ }^{78}$

\section{CONCLUSION}

In surveying British military law and operational methods in Palestine in the late 1930s, it is clear that embedded in the official "system" of repression was a targeting of Palestinian civilians that was brutal and could lead to atrocities. It is not clear which came first: the (often) brutal operational methods or the laws and collective ideas, traditions, and norms that validated them-not surprising when one considers the traditional British preference for flexible practice over codified theory.

Troops in Palestine used force across a spectrum: not so much minimum force as necessary force and, at times, excessive force, which itself was often "necessary" to secure Britain's objective of defeating the rebels by targeting their civilian support base. That said, the Colonial Office, the high commissioner, and civilian sensibilities generally helped to establish "red lines" that the security forces could not cross. Moreover, the humanist tendencies of some servicemen countered the hawkishness of others. The army was pulled in different directions, being asked to repress the Palestinians quickly to free up forces for a possible war in Europe, but without too much "frightfulness." The British high command tolerated the less blatant abuses committed by its men 
in the field, but senior officers based in Haifa and Jerusalem were sensitive to charges of abuse, politically if not morally, and so it was junior officers in the field who were intimately involved in any excesses. The Anglican bishop in Jerusalem put it succinctly, writing how outrages "are not officially sanctioned although they have not been officially regretted." 79 The result was a tension between violence and moderation in the British system; the police and army behaved differently, and many officials opposed the violence.

Given these competing and conflicting demands, British officers compared their position unfavorably to other European countries that were much harsher in suppressing colonial revolts. General Wavell, the senior British military commander in Palestine at the time, remarked to a colleague, "If the Germans were in occupation in Haifa we'd not have any bloody trouble from the Arabs." ${ }^{80}$ In some comparative sense, Wavell was right, though such a perspective smacks of an apology for the military power on which empires depend.

\section{NoTES}

1. C. E. Callwell, Small Wars: Their Principles and Practices (London: HMSO, 1906), p. 145.

2. Callwell, Small Wars, p. 148.

3. Callwell, Small Wars, p. 148.

4. Charles Gwynn, Imperial Policing (London: Macmillan, 1934); H. J. Simson, British Rule and Rebellion (Edinburgh: Blackwood, 1937).

5. War Office, Issued by Command of the Army Council, Manual of Military Law, 1929 (London: HMSO, 1929); War Office, By Command of the Army Council, Notes on Imperial Policing, 1934 (London: War Office, 30 January 1934); War Office, By Command of the Army Council, 5 August 1937, Duties in the Aid of the Civil Power (London:War Office, 1937).

6. War Office, Manual of Military Law, p. 103.

7. War Office, Manual of Military Law, p. 343; War Office, Notes on Imperial Policing, pp. 12, 39-41.

8. War Office, Manual of Military Law, p. 255.

9. Norman Bentwich, ed., Legislation of Palestine 1918-25, vol. 1 (Whitehead: Government of Palestine, 1926), pp. 246-49.

10. The Tiger and the Rose:A Monthly Journal of the York and Lancaster Regiment 13, no. 16 (October 1936), p. 390 .

11. Diary, Forster papers, GB 1650109, pp. 6, 74-75, 78ff, 105, Middle East
Centre [MEC], St.Antony's College, Oxford; Manshiya Exploits by the Three British Policemen in Mufti during the Night of the 23-24 Oct. 1938, in J \& E Mission papers, GB 165-0161, Box 66, File 2, MEC; J \& E Mission papers, GB 165-0161, Box 66, File 5, MEC.

12. "Palestine: Martial Law Order Issued," Palestine Post, 30 September 1936.

13. Simson, British Rule, pp. $96 \mathrm{ff}, 103$.

14. Essex Regiment Gazette 6, no. 46 (March 1938), p. 282.

15. Letter, Burr to Parents, 24 February 1938, Burr papers, 88/8/1, Imperial War Museum Documents [IWMD], London; The Disturbances of 1936-Cause and Effect (General Political No. 5), U.S. Consulate General to State Department, 6 June 1936, signed Leland Morris, U.S. Consul General, 867 N.00/311, p. 8, National Archives and Records Administration II, College Park. 16. Abdel Rahman,"British Policy Towards the Arab Revolt in Palestine, 1936-39" (PhD thesis, University of London, 1971), pp. 140-42; Yuval ArnonOhanna, Falabim ba-Mered ha-Aravi be-Eretz Israel, 1936-39 [The Felaheen during the Arab Revolt in the Land of Israel] (Tel Aviv: University Press, 1978), p. 33; Bahjat Abu Gharbiyah, Fi Khidamm alNidal al-Arabi al-Filastini: Mudbakkarat al-Munadil Babjat Abu Gharbiyab [In the Midst of the Struggle for the Arab Palestinian Cause:The Memoirs of Freedom Fighter Bahjat Abu Gharbiyah] 
(Beirut: Institute for Palestine Studies [IPS], 1993), pp.60-61; al-Difa， 17 June 1936; The Wasp:The Journal of the 16th Foot 8 , no. 5 (March 1937), p. 267; John Newsinger, The Blood Never Dried (London: Bookmarks, 2002), pp. 131ff.

17. Al-Difa', 17 June and 23 July 1936 ; Abu Gharbiyah, Fi Khidamm al-Nidal,pp. 60-61.

18. Filastin, 19 June 1936.

19. "Pieces of War,"Typed Memoir, Simonds papers, $08 / 46 / 1$, p. 149, IWMD.

20. The Arabs with glee printed up 10,000 copies of the court's critical conclusions for public distribution. Edward KeithRoach, Pasha of Jerusalem: Memoirs of a District Commissioner under the British Mandate (London: Radcliffe, 1994), p. 185; Y. Eyal, Ha-Intifada ha-Rishona: Dikuy ha-Mered ha-Aravi al yedey ha-Tzava haBriti be-Eretz Israel, 1936-39 [The First Intifada:The Suppression of the Arab Revolt by the British Army, 1936-39] (Tel Aviv: Ma'arahot, 1998), p. 110; Walid Khalidi and Yassin Suweyd, Al-Qadiyya al-Filastiniyya wa al-Khatar al-Sabyuni [The Palestinian Problem and the Zionist Danger] (Beirut: IPS, 1973), p. 234.

21. Filastin, 19 June 1936. See also, Mustafa Kabha, The Palestine Press as Shaper of Opinion, 1928-39: Writing up a Storm (Ilford:Vallentine Mitchell, 2006).

22. Al-Difa', 17 June and 23 July 1936.

23. Abu Gharbiyah, Fi Kbidamm alNidal, p. 59.

24. Nicholas Bethell, The Palestine Triangle: The Struggle for the Holy Land, 1935-48 (London: Futura, 1980), p. 49; W.V. Palmer, "The Second Battalion in Palestine," in H. D. Chaplin, ed., The Queen's Own Royal West Kent Regiment (London: Michael Joseph, 1954), p. 102.

25. Letter, Burr to Parents, 9 Sept. 1938, Burr papers, 88/8/1, IWMD.

26. Monthly News Letter No. 2, 2nd Battalion, Lincolnshire Regiment, 1-30 September 1936 in Abdul-Latif al-Tibawi papers, GB 165-1284, MEC.

27. For village searches, see H. M Wilson, Diary of School Year in Palestine, 1938-39, about 31,000 words, Wilson papers, GB 165-0302, pp. 36ff, MEC; see also the correspondence and pictures in $\mathrm{J}$ \& E Mission papers, GB 165-0161, Box 61, File 3, MEC.

28. D. Scott Daniell, The Royal Hampshire Regiment, vol. 3 (Aldershot: Gale, 1955), p. 34.
29. "Palestine:The First Intifada,"

Timewatch, BBC, 27 March 1991.

30. Fred Howbrook, 4619, p. 2 , Imperial War Museum Sound Archive [IWMSA], London.

31. J. S. S. Gratton, 4506 , pp. 14-15, IWMSA.

32. Diary, 22 January 1938, Tegart papers, GB 165-0281, Box 4, MEC.

33. Maj. Gen. H. E. N. Bredin, 4550, p. 10, IWMSA.

34. Diary, Wilson papers, GB 165-0302, pp. 28-29, MEC.

35. John Connell, Wavell: Scholar and Soldier (London: Collins, 1964), p. 194; Eric and Andro Linklater, The Black Watch (London: Barrie, 1977), p. 175.

36. Ha'Aretz, 7-8 November 1937.

37. Major White, Diary, 7 November 1937, Relating to Service in Palestine, 1974-04-24-8, National Army Museum, London.

38. Correspondence, Edward Horne (formerly of the Palestine police) to author, 5 September 2009.

39. "Pieces of War,"Typed Memoir, Simonds papers, 08/46/1, p. 148, IWMD.

40. Memorandum of Protest from the Religious Scholars to the High Commissioner about the Police Aggression against Mosques and Houses, 1 June 1936, in Akram Zua ytir, Watha'iq al-Haraka al-Wataniyya al-Filastiniyya, 1918-39: Min Awraq Akram Zua'ytir [Documents of the Palestinian National Movement, 1918-39: From the Papers of Akram Zua ytir] (Beirut: IPS, 1979), p. 436.

41. Memorandum of the Arab Higher Committee to the High Commissioner to Protest on the Laws and the Behaviour of the Authorities, Jaffa, 22 June 1936 in A.W. Kayyali, Watha'iq al-Muqawama al-Filastiniyya al 'Arabiyya Didd al-Ibtilal alBaritani wa al-Sabyuniyya [Documents of the Palestinian Arab Resistance] (Beirut: IPS, 1968), pp. 407-11.

42. Abu Gharbiyah, Fi Kbidamm alNidal, p. 60.

43. Report dated 5 May 1939, 10 pages in J \& E Mission papers, GB 165-0161, Box 62, File 1, p. 3, MEC.

44. Palmer,"Second Battalion," p. 100. £.P1 equalled £1 U.K. sterling.

45. Abu Gharbiyah, Fi Kbidamm al-Nidal, pp. 60-61; Ha'Aretz (Evening Issue), 22 December 1937.

46. Report dated 5 May 1939, 10 pages in J \& E Mission papers, GB 165-0161, 
Box 62, File 1, p. 1, MEC; Ha'Aretz, 18

August 1938.

47. Rosemary Sayigh, The Palestinians:

From Peasants to Revolutionaries

(London: Zed Books, 2007), p. 25.

48. Abu Gharbiyah, Fi Khidamm

al-Nidal, pp. 60-61; Ha'Aretz (Evening

Issue), 22 December 1937.

49. Jack Binsley, Palestine Police

Service (Montreux: Minerva, 1996), p. 99.

50. Letter, Burr to Parents, n.d.

[December 1937], Burr papers, 88/8/1, IWMD.

51. See the files in $M 4826 / 26$, Israel State Archive, Jerusalem.

52. Palmer, "Second Battalion," p. 85; Ha'Aretz, 20 February 1938.

53. Letter, Burr to Parents, 24 February 1938, Burr papers, 88/8/1, IWMD; J \& E Mission papers, GB 165-0161, Box 61, File 3, MEC and material in J \& E Mission papers, GB 165-0161, Box 66, File 2.

54. Request for Intercession, Abdulla Family by Attorney for Convicts, 7 July 1938, in J \& E Mission papers, GB 1650161, Box 66, File 3, p. 3, MEC.

55. For example, a special order to the two battalions tasked with retaking the Old City of Jerusalem from the rebels in October 1938 stated:"Any attempts, even the most minor, at looting, scrounging or souveniring by individual troops or police will be rigorously suppressed." Special Order by Brig. I. Grant, CO, 20th Infantry Brigade, October 1938, in J \& E Mission papers, GB 165-0161, Box 61, File 4, MEC.

56. Extracts from the CO's Quarterly Letter for period ending 31 December 1937 in Essex Regiment Gazette 6, no. 46 (March 1938), p. 282.

57. Gilbert Shepperd, 4597, p. 64 , IWMSA. Quote from Desmond Woods, 23846, IWMSA.

58. Woods, 23846, IWMSA

59. Arthur Lane, 10295 , p. 18, IWMSA.

60. Howbrook, 4619, pp. 35-36, IWMSA.

61. Letter, P. Cleaver to Aunt, 10

February 1937, Cleaver papers, GB 165 0358, MEC.

62. Lane, 10295 , pp. 23-24, IWMSA.

63. A Notice of the Office of the Arab Revolt about the Tragedy of 'Atil, 11 December 1938, in Zua ytir, Watha'iq alHaraka, pp. 529, 545.

64. Binsley, Palestine Police Service, pp. 104-05.

65. Letter, Burr to Parents, March 1938, Burr papers, 88/8/1, IWMD.
66. Hugh Foot, $A$ Start in Freedom (London: Hodder, 1964), pp. 51-52; mixed Hebrew-English files in S25/10685, 3156 and 8768, Central Zionist Archive, Jerusalem.

67. The Alleged Ill-treatment of Prisoners by F. Newton (sent to the Howard League for Penal Reform), 15 April 1938, in J \& E Mission papers, GB 165-0161, Box 65, File 5, p. 94, MEC.

68. Keith-Roach, Pasha of Jerusalem, p. 191; Edward Tinker, 4492, pp. 34-35, IWMSA; Charles Smith "Two Revolts in Palestine:An Examination of the British Response to Arab and Jewish Rebellion, 1936-48" (PhD thesis, Cambridge University, 1989), pp. 114-19; Anwar Nusseibeh, 28 March 1977, Thames TV Material (not on open access), Lever Arch file: Nigel Maslin, Imperial War Museum Film Archive, London.

69. Letters, O'Connor to Wife, 22 October, 2-3 November 1938, O'Connor papers, 3/1, Liddell Hart Centre for Military Archives, London.

70. Author interview, Bahjat Abu Gharbiyah,Amman, 21 June 2009; HC (Hansard) Deb, 28 June 1939, vol. 349, cc401-02.

71. Tom Segev, One Palestine, Complete (New York: Holt, 2000), pp. 416-17.

72. Typed two-page document by Edward Keith-Roach, untitled or dated, at the end of which is added pencilled comment, Keith-Roach papers, in possession of Mrs. C.Ames-Lewis, London.

73. A Letter from the Fighter Arrested, Subhi al-Khadra, 20 September 1938, in Zua 'ytir, Watha'iq al-Haraka, pp. 505-06, 548.

74. Statement about the Torture of Arabs Arrested in Military Camps and Prisons, 1938-39, in Zua' ytir, Watha'iq al-Haraka, pp. 548, 579, 594, 601; Subhi Yasin, Al-Thawra al- Arabiyya al-Kubra (fi Falastin) 1936-1939 [The Great Arab Revolt in Palestine, 1936-1939] (Damascus: Shifa `Amru Haifa, 1959), p. 47. 75. See Palestine Prisons for Howard League for Penal Reform, 6 April 1938, in J \& E Mission papers, GB 165-0161, Box 65, File 5, pp. $76 \mathrm{ff}, \mathrm{MEC}$ and Allegations of Ill-treatment of Arabs by British Crown Forces in Palestine (translated from the Arabic by Frances Newton, 19 June 1939), in J \& E Mission papers, GB 165-0161, Box 65, File 5, pp. 141-43. 
76. For a full discussion of al-Bassa and Halhul, see Matthew Hughes, "The Practice and Theory of British Counter-Insurgency: The Histories of the Atrocities at the Palestinian Village of al-Bassa and Halhul, 1938-39," Small Wars and Insurgencies 20, no. 3 (September 2009), pp. 528-50. 77. Woods, 23846, IWMSA; letter, Raymond Cafferata to Wife, 22 October 1938, Cafferata papers, in possession of Mr. John Robertson (subsequently moved to the MEC); Harry Arrigonie,
British Colonialism: 30 Years Serving Democracy or Hypocrisy (Bideford: Lazarus, 1998), pp. 35-36.

78. J \& E Mission papers, GB 1650161, Box 66, Files 1-2, MEC.

79. Anglican Bishop in Jerusalem to Miss Trevelyan, 23 June 1939, in J \& E Mission papers, GB 165-0161, Box 62, File 1 , MEC.

80. Conversation, Lt. Gen. A. Wavell to Brig. J. Evetts, in P. C. Munn, 4503, tape 3, IWMSA. 